\title{
ANALYSIS OF SOME HEALTH INDICATORS WITH FORMER MINERS
}

\author{
Yanakieva T. ${ }^{1}$, T. Turnovska ${ }^{2}$, M. Panova ${ }^{3}$, D. Terzieva ${ }^{3}$ \\ ${ }^{1}$ Regional Inspectorate of Protection and Control of Public Health - Haskovo, ${ }^{2}$ Medical University - \\ Plovdiv, ${ }^{3}$ St. George University Multifunctional Hospital for Active Healthcare - Plovdiv
}

\author{
Reviewed by: Assoc. Prof. B. Kavaldjieva
}

\begin{abstract}
Up to 1998-1999 the Saje Mine operated in the village of Sarnitza (extraction of lead-zinc ores) and the wastewaters from it were draining away in the Trakietz Dam Lake. This reservoir was used, as recently as three years ago, for drinking-water supply to the city of Haskovo. The population which has consumed water for drinking and household needs from the nearby Trakietz Dam Lake is nearly 26000 people. Because of the significant effect of heavy metals and ionizing radiation on human health we set as our goal to study the concentration of some of them in biological material collected from former miners and people living in close proximity to old mines. An active survey was done of all studied people. The average concentrations in blood of miners: $\mathbf{P b}$ $66.50 \mathrm{mg} / \mathrm{l}, \mathrm{Cd}-1.12 \mathrm{mg} / \mathrm{l}, \mathrm{Cu}$ in blood serum - 15.68, $\mathrm{Zn}$-in blood serum - 18.58mg $/ \mathrm{l}, \mathrm{As}$ - in urine test-13.84 $\mathrm{mg}$ /l. The average concentrations in people: $\mathrm{Pb}-149.13 \mathrm{mg} / \mathrm{l}, \mathrm{Cd}-3.37 \mathrm{mg} / \mathrm{l}, \mathrm{Cu}$ serum-15.69 mg $/ \mathrm{l}, \mathrm{Zn}-16.22 \mathrm{mg} / \mathrm{l}$, As $-18.72 \mathrm{mg} / \mathrm{l}$. Conclusion: 1.Increased levels of $\mathrm{Pb}$ are found in $4.34 \%$ and boundary values in $21.7 \%$ of the former miners which may be the reason for the larger percentage of miners with high blood pressure, as well as the big share of diseases of the nervous system (8.69\%). 2. Higher values of $\mathrm{Cd}$ were found in $43.48 \%$ of the miners, which correlates with the increased percentage of kidney diseases in the exposed group, and could be due to professional exposure in the past. 3.There is no evidence of $\mathrm{Cd}$ contamination of drinking water. 4 . The content of $\mathrm{Cu}$ and $\mathrm{Zn}$ in the serum of all tested individuals is within the referential boundaries. 5 . The concentration of As in the urine samples of all tested individuals is within the referential values.
\end{abstract}

Key words: exposure, heavy metals, health risk, health assessment

Inhalation of toxic substances may considerably increase the health risk of the emergence of various diseases or disorders in the reproductive function (15). Lead impairs haematopoiesis, damages the central and peripheral nervous systems, has neurotoxic effect, passes the placental barrier, and may harm the foetus before the $12^{\text {th }}$ gestational week. Cadmium and lead are classified as potential carcinogens for a human being in Gr. 2 B (1); cadmium is confirmed to have a teratogenic, carcinogenic, and a potential mutagenic effect (20).

Millions of people are exposed to increased concentrations of As, mainly in drinking water, but also in the industrial emissions as a result of the inhalation of arsenic aerosols (13). Inorganic As is a potential human carcinogen, Group 1(3) and a primary toxicant (13). Early exposure to these pollutants in the environment results in subsequent neurotoxicity in children (10). Arsenic is metabolized into methylarsenic acid and dimethylarsenic acid which are excreted in the urine (13). A number of experimental studies of animals confirm the subsequent effect from intrauterine exposure to arsenic, namely - various forms of cancer. Besides these, endocrine effects, immune suppression, neurotoxicity, etc. are also possible (13).
There are considerable negative effects on the health from exposure to ionizing rays as well. In the specialized literature there are numerous reports about an increased carcinogenic, mutagenic risk, about damage to the nervous, cardiovascular system, immune, digestive, etc. systems. Small-dose irradiation for a prolonged period of time induces the emergence of cancerogenesis, leukemia, cataract, premature ageing $(2,5,16,17)$.

A number of deposit fields for the extraction of uranium and polymetal ores have operated in the city of Haskovo and in the Mineral Bath Municipality. Up to 1998-1999 the Saje Mine operated in the village of Sarnitza (extraction of lead-zinc ores) and the wastewaters from it were draining away in the Trakietz Dam Lake. This reservoir was used, as recently as three years ago, for drinking-water supply to the city of Haskovo. The population which has consumed water for drinking and household needs from the nearby Trakietz Dam Lake is nearly 26000 people. Metals dredged in lakes retain their bioactivity 25 years after precipitation. These sediments are contaminated with $\mathrm{Cd}, \mathrm{Zn}$ and other elements (12). $\mathrm{Pb}$ content is increased in ultrabasic and basic to acid magmatic rocks (4). Because of the significant effect of heavy metals and ionizing radiation on human 
health we set as our goal to study the concentration of some of them in biological material collected from former miners and people living in close proximity to old mines.

\section{SETTING AND METHODS}

Exposition tests were run on 23 people who had worked in the mining and extracting industry and on 10 people from the population living in close proximity to the mines. The samples were tested in the Central Clinical Laboratory of the St. George University Multifunctional Hospital for Active Healthcare in the city of Plovdiv. The heavy metals were examined using atomic absorption spectrophotometry with a Zeeman 5100 PC, Perkin-Elmer, USA atomic absorption spectrophotometer.

A segment study was carried out with the aim to clarify the current exposition of the population at the particular moment, 10 years after the closing-down of the mines.

An active survey was done of all studied people. A total number of 33 people were surveyed, of these - 23 people $(69.7 \%)$ who had worked in the mining and extracting industry and 10 people $(30.3 \%)$ who had been living for 31 years on average in the studied towns and villages situated in proximity to the mines.

\section{FINDINGS AND CONSIDERATIONS}

The conducted toxicological tests on the 10 people living in the vicinity of the mines gave the following results (table 1):

Table 1. Content of the $\mathrm{Pb}, \mathrm{Cd}, \mathrm{Cu}, \mathrm{Zn}$ in blood and $\mathrm{As}$ in urine of the unexposed population

\begin{tabular}{|c|c|c|c|c|c|}
\hline $\begin{array}{c}\text { Examina } \\
\text {-tion } \\
\text { indices }\end{array}$ & $\begin{array}{l}\text { Admissible } \\
\text { value }\end{array}$ & $\mathbf{N}$ & Mean & $\begin{array}{c}\text { Std. } \\
\text { Deviatio } \\
n\end{array}$ & $\begin{array}{l}\text { Std. } \\
\text { Error }\end{array}$ \\
\hline $\mathrm{Pb} \mu \mathrm{g} / 1$ & $0-254 \mu \mathrm{g} / 1$ & 10 & 66.50 & 28.78 & 9.102 \\
\hline $\mathrm{Cd} \mu \mathrm{g} / 1$ & $\begin{array}{c}\text { Non-smokers: } \\
0-1.2 \mu \mathrm{g} / 1 \\
\text { Smokers: } \\
\text { до } 7.6 \mu \mathrm{g} / 1\end{array}$ & 10 & 1.12 & 0.37059 & 0.117 \\
\hline $\begin{array}{l}\mathrm{Cu} \\
\mu \mathrm{mol} / \mathrm{l}\end{array}$ & $12.3-22.4 \mu \mathrm{g} / 1$ & 10 & 15.68 & 3.82123 & 1.208 \\
\hline $\mathrm{Zn} \mu \mathrm{mol} / \mathrm{l}$ & $12.3-22.4 \mu \mathrm{g} / 1$ & 10 & 18.58 & 3.33579 & 1.055 \\
\hline $\begin{array}{l}\text { As in } \\
\text { urine/24 } \\
\text { hours } \\
\text { diuresis } \\
\mu \mathrm{g} / 1\end{array}$ & to $100 \mu \mathrm{g} / \mathrm{l}$ & 10 & 13.84 & 8.82514 & 2.791 \\
\hline
\end{tabular}

The published data show that the values of the toxic indicators in the people living in the villages situated in the vicinity of old mines are within the referential limits. A slight excess, compared to the admissible levels, is found in $50 \%$ of the studied subjects only for the $\mathrm{Cd}$ indicator in blood. The conducted toxicological tests on the people who had worked in the mining and extracting industry - 23 people, gave the following results (Table 2):

Table 2. Content of the $\mathrm{Pb}, \mathrm{Cd}, \mathrm{Cu}, \mathrm{Zn}$ in blood and $\mathrm{As}$ in urine of the exposed population

\begin{tabular}{|l|c|c|c|c|c||}
\hline \hline $\begin{array}{l}\text { Examina } \\
\text { tion } \\
\text { indices }\end{array}$ & $\begin{array}{c}\text { Admissible } \\
\text { value }\end{array}$ & $\mathbf{N}$ & Mean & $\begin{array}{c}\text { Std. } \\
\text { Deviation }\end{array}$ & $\begin{array}{c}\text { Std. } \\
\text { Error }\end{array}$ \\
\hline $\mathrm{Pb} \mu \mathrm{g} / 1$ & $0-254 \mu \mathrm{g} / 1$ & 23 & 149.1304 & 72.63064 & 15.14453 \\
\hline $\mathrm{Cd}$ & $\begin{array}{c}\text { Nonsmokers: } \\
0-1.2 \mu \mathrm{g} / 1 \\
\text { Smokers: } \mathrm{go} / 1 \\
7.6 \mu \mathrm{g} / 1\end{array}$ & 23 & 3.3696 & 5.37261 & 1.12027 \\
\hline $\mathrm{Cu}$ & $\begin{array}{c}12.3-22.4 \mu \mathrm{g} / 1 \\
\mu \mathrm{mol} / 1\end{array}$ & 23 & 15.6913 & 2.83419 & 0.59097 \\
$\mathrm{Zn}$ & $12.3-22.4 \mu \mathrm{g} / 1$ & 23 & 16.2243 & 2.72883 & 0.56900 \\
$\mu \mathrm{mol} / 1$
\end{tabular}

$\mathrm{Pb}$ has a level above the admissible values in $4.34 \%$ of the miners, and in $21.7 \%$ has values close to the referential ones. In population, exposed for a long time to low concentrations of lead aerosols there are reports of disorders, first and foremost, in the hemoglobin synthesis, the erythropoiesis, the nervous system, the reproductive system, the immune system, the cardio-vascular system, including higher arterial tension. The latter can account for the increased percentage of cardio-vascular diseases in the exposed individuals. The increased levels of $\mathrm{Pb}$ in the blood predispose to the emergence of cardio-vascular diseases, blood diseases and disorders, diseases of the nervous system, the reproductive system, etc. $(6,8,20)$. The latest studies with rats demonstrate that exposure to $\mathrm{Pb}$ during the time of development of the brain predetermines the expression and regulation of the amyloid precursor protein APP and is an amyoidogenic B-amyloid product in senior age (9). Exposure to $\mathrm{Pb}$ during the time of development changes lead levels and the intracellural distribution of amyloid plates in the frontal lobe of the cerebral cortex.

Lead is a cumulative poison with an extended period of release: ranging from a few days to 25 years $(11,6,12,14)$. Adolescents and children are extremely sensitive to low concentrations of $\mathrm{Pb}$ which may cause behavior problems, learning problems, and decline in intellect $(11,14)$.

The International Occupational Hygiene Association has come to the conclusion that inorganic lead content in the blood up to a level of $696.19 \mu \mathrm{g} / \mathrm{l}$ has an acceptable effect; this approximately corresponds to an average concentration in the air of $150 \mathrm{mg} / \mathrm{m} 3$ and 40-hours' weekly exposure, i.e. with an 8-hour work day and a five-day work week (7). Nevertheless, some studies have determined a decrease in the glomerular filtration with $\mathrm{Pb}$ in the blood $<200 \mathrm{mg} / \mathrm{l}$, even with a concentration of $\mathrm{Pb}$ in the blood $<100 \mathrm{mg} / \mathrm{l}(8)$. With concentrations of $\mathrm{Pb}$ in the blood from 49 to $236 \mathrm{mg} / \mathrm{l}$ the level of the active form of vitamin D-1.25 dihydroxivitamin $\mathrm{D}$ decreases (8). The $\mathrm{Cd}$ values are also 
higher in $43.48 \%$ of the studied miners, $8.7 \%$ of whom are smokers, and $34.8 \%$ - non-smokers. This explains the high percentage of diseases of the respiratory system, in the exposed group. The latter increases the risk in non-smokers of developing chronic lung diseases, as well as oncological diseases, which are more common with smokers. There is a heightened risk of damage to the kidneys, liver, and bones of the studied individuals $(6,20)$. The risk to the exposed people for this indicator is $1.25 \%$ higher, compared to the same one for the unexposed group. This risk is doubled in the studied smokers, who comprise $33.3 \%$ of the exposed individuals. Smoking presents a great risk in terms of a rational impact, since, with smoke, radioactive elements enter the organism, and those are mostly radium and polonium. $(18,19)$. With chronic exposure $\mathrm{Cd}$ is accumulated in the kidney proximal tubules (1). The latter may explain the increased percentage of kidney diseases in the exposed group. Because of the higher concentration of $\mathrm{Cd}$ in the blood samples of both the exposed, and unexposed group, while most of the studied individuals are non-smokers, we assume its higher content in the surrounding environment, namely, in minerals, from which the particular ore for the area is extracted (4).

Since we do not find an increased content of $\mathrm{Cd}$ in drinking water, we suppose that the main way of Cd entering the organism is the respiratory tract, through inhalation of cadmium dust and cadmium oxide (3), although there are no massive industrial sources of pollution in the area.

The $\mathrm{Cu}$ values in the blood serum, in the exposed group, vary from 11.3 to $20.5 \mu \mathrm{g} / 1$. In $8.7 \%$, the levels of $\mathrm{Cu}$ and $\mathrm{Zn}$ are below the referential ones.

The values of $\mathrm{Zn}$ in the blood serum, in the exposed group vary from 12.08 to $21.86 \mu \mathrm{g} / \mathrm{l}$. The $\mathrm{Cu}$ and $\mathrm{Zn}$ levels in the rest of the studied individuals are within the referential limits. The concentrations of As in the urine samples of the studied exposed and unexposed group are within the referential values. The arsenic in the urine samples of the exposed individuals varies from $2.24 \mu \mathrm{g} / 1$ to $58.9 \mu \mathrm{g} / \mathrm{l}$, which is within the boundaries of the referential values - up to $100 \mathrm{mg} / \mathrm{l}$ for 24 hours. Arsenic is highly cumulative, it builds up in the skin and skin appendages, in the bones and muscles, it causes dermal lesions, peripheral neuropathy, peripheral vessel disease, but such changes were not found in the participants in the study (1).

The results from the survey show that $51.5 \%$ of the studied individuals have secondary education, $21.2 \%$ - elementary, $18.2 \%$ - basic school education, and $9.1 \%$ - higher education. The length of the work day - 8 hours on average, with 2 days off. Vacation - 20 work days a year, on average. Smokers comprise $33.3 \%$ of all studied individuals; the remaining $66.7 \%$ are non-smokers. $54.5 \%$ of the participants in the study consume alcohol, $39.4 \%$ do not consume alcohol. The smokers have been smoking for approximately 20 years, 6 cigarettes per day on average. The alcohol consumers have been drinking 1-2 times, a single dose of roughly $60 \mathrm{~g}$. It is evident that the highest percentage is of cardio-vascular diseases, articular, respiratory, and professional diseases. Amongst cardio-vascular diseases, arterial hypertension is the most frequent; $13.04 \%$ of the exposed individuals report about having suffered a heart attack or a stroke. There is also an increase in the percentage of professional diseases, diseases of the kidneys and the nervous system, which correlates with the chronic exposure to $\mathrm{Pb}$ and $\mathrm{Cd}$ of the exposed individuals, determined through the expositional tests $(3,6)$.

Table 3. Results from the survey

\begin{tabular}{|c|c|c|c|}
\hline $\begin{array}{c}\text { Group of diseases } \\
\text { (ICD-10) }\end{array}$ & $\begin{array}{c}\text { Frequency } \\
\text { occur with } \\
\text { exposure } \\
\text { group (\%) }\end{array}$ & $\begin{array}{c}\text { Frequency } \\
\text { occur with } \\
\text { non-exposure } \\
\text { group }(\%)\end{array}$ & $\begin{array}{c}\text { Diseases } \\
\text { in the past } \\
(\%)\end{array}$ \\
\hline $\begin{array}{l}\text { IX.(I00-I99). } \\
\text { Diseases of the } \\
\text { circulatory system }\end{array}$ & 26.09 & 50 & 21,12 \\
\hline $\begin{array}{l}\text { XIII.(M00-M99) } \\
\text { Diseases of the } \\
\text { musculoskeletal } \\
\text { system and } \\
\text { connective tissue }\end{array}$ & 13.04 & 10 & 8.69 \\
\hline $\begin{array}{l}\text { X.(J00-J99) } \\
\text { Diseases of the } \\
\text { respiratory system }\end{array}$ & 13.04 & 10 & 6.06 \\
\hline $\begin{array}{l}\text { XX.(X40-X49) } \\
\text { Accidental } \\
\text { poisoning by and } \\
\text { exposure to } \\
\text { noxious substances }\end{array}$ & 13.04 & 0 & 9.09 \\
\hline $\begin{array}{l}\text { XIV.(N00-N99) } \\
\text { Diseases of the } \\
\text { genitourinary } \\
\text { system }\end{array}$ & 4.35 & 10 & 3.03 \\
\hline $\begin{array}{l}\text { VI.(GOO-G99): } \\
\text { Diseases of the } \\
\text { nervous system }\end{array}$ & 8.7 & 0 & 6.06 \\
\hline $\begin{array}{l}\text { IV. (E-10-E14): } \\
\text { Diabetes mellitus }\end{array}$ & 8.7 & 0 & 3.03 \\
\hline $\begin{array}{l}\text { XII.(L00-L99) } \\
\text { Diseases of the } \\
\text { skin and } \\
\text { subcutaneous } \\
\text { tissue }\end{array}$ & 8.7 & 0 & 3.03 \\
\hline $\begin{array}{l}\text { VII.(HOO-H59) } \\
\text { Diseases of the eye } \\
\text { and adnexa }\end{array}$ & 0 & 10 & 3.03 \\
\hline $\begin{array}{l}\text { XI. (K20-K31) } \\
\text { Diseases of } \\
\text { oesophagus, } \\
\text { stomach and } \\
\text { duodenum }\end{array}$ & 4.35 & 10 & 3.03 \\
\hline
\end{tabular}

The carcinogenic and mutagenic effect of radiation on a human organism has been confirmed (5). Specialized literature points out the possibility of an increased frequency of chro- 
mosome mutations in the peripheral lymphocytes, proportionate to the received dose, as well as of a greater frequency of cases of leukemia and malignant tumors in the irradiated individuals, in comparison with the average ones for the respective countries (16). In order to establish whether professional exposure had any repercussions on the miners' offspring, we analyzed the data on congenital and hereditary diseases amongst the children of the studied people.

The survey results showed that the miners' children did not yield data pointing to carcinogenesis and mutagenesis. Three of the studied individuals' children have high blood pressure, and one has chronic bronchitis (17.4\%). None of the rest report on having chronic diseases. The submitted survey data do not indicate any hereditary predispositions, but rather - a hazardous lifestyle and existing factors of the environment which predispose to diseases.

Table 4. Comparison of the survey data on smokers and non-smokers

\begin{tabular}{||l|c|c|c||}
\hline \multirow{2}{*}{ Group } & \multicolumn{2}{|c||}{ Do you smoke cigarette? } & Total \\
\cline { 2 - 4 } & NO & YES & \\
\hline $\begin{array}{l}\text { Exposure } \\
\text { people/number }\end{array}$ & 13 & 10 & 23 \\
\hline $\begin{array}{l}\text { \% of group } \\
\text { \% of smokers }\end{array}$ & $56.5 \%$ & $43.5 \%$ & $100 \%$ \\
\hline $\begin{array}{l}\% \text { of total count } \\
\text { examine people }\end{array}$ & $39.4 \%$ & $30.3 \%$ & $69.7 \%$ \\
\hline $\begin{array}{l}\text { Nonexposure } \\
\text { people/number }\end{array}$ & 9 & 1 & 10 \\
\hline$\%$ of group & $90.0 \%$ & $10.0 \%$ & $100 \%$ \\
\hline$\%$ of smokers & $40.9 \%$ & $9.1 \%$ & $30.3 \%$ \\
\hline $\begin{array}{l}\% \text { of total count } \\
\text { examine people }\end{array}$ & $27.3 \%$ & $3.0 \%$ & $30.3 \%$ \\
\hline TOTAL: & 22 & 11 & 33 \\
\hline $\begin{array}{l}\% \text { of group } \\
\text { \% of smokers }\end{array}$ & $66.7 \%$ & $33.3 \%$ & $100 \%$ \\
\hline $\begin{array}{l}\% \text { of total count } \\
\text { examine people }\end{array}$ & $66.7 \%$ & $33.3 \%$ & $100 \%$ \\
\hline \hline
\end{tabular}

The comparison of these data with the anamnestic data on bad habits shows that these individuals are smokers which, according to us, explains the obtained result.

\section{CONCLUSION}

1. Increased levels of $\mathrm{Pb}$ are found in $4.34 \%$ and boundary values in $21.7 \%$ of the former miners which may be the reason for the larger percentage of miners with high blood pressure, as well as the big share of diseases of the nervous system $(8.69 \%)$.
2. Higher values of $\mathrm{Cd}$ were found in $43.48 \%$ of the miners, which correlates with the increased percentage

Table 5. Comparison of the survey data on alcohol consumption

\begin{tabular}{|c|c|c|c|c|}
\hline \multirow{2}{*}{ GROUP } & \multicolumn{3}{|c|}{ Do you use alcohol? } & \multirow[t]{2}{*}{ Total } \\
\hline & $\mathrm{NO}$ & YES & Sometimes & \\
\hline $\begin{array}{l}\text { Number of } \\
\text { exposure people }\end{array}$ & 5 & 17 & 1 & 23 \\
\hline$\%$ of group & $21.7 \%$ & $73.9 \%$ & $4.3 \%$ & $100 \%$ \\
\hline $\begin{array}{l}\% \text { of using } \\
\text { alcohol }\end{array}$ & $38.5 \%$ & $94.4 \%$ & $50 \%$ & $69.7 \%$ \\
\hline $\begin{array}{l}\% \text { of total count } \\
\text { examine people }\end{array}$ & $15.2 \%$ & $51.5 \%$ & $3.0 \%$ & $69.7 \%$ \\
\hline $\begin{array}{l}\text { Number of } \\
\text { non-exposure } \\
\text { people }\end{array}$ & 8 & 1 & 1 & 10 \\
\hline$\%$ of group & $80 \%$ & $10 \%$ & $10 \%$ & $100 \%$ \\
\hline $\begin{array}{l}\% \text { of using } \\
\text { alcohol }\end{array}$ & $61.5 \%$ & $5.6 \%$ & $50 \%$ & $30.3 \%$ \\
\hline $\begin{array}{l}\% \text { of total } \\
\text { examine people }\end{array}$ & $24.2 \%$ & $3.0 \%$ & $3.0 \%$ & $30.3 \%$ \\
\hline Total/Count & 13 & 18 & 2 & 33 \\
\hline$\%$ of group & 39.4 & 54.5 & 6.1 & 100 \\
\hline $\begin{array}{l}\% \text { of using } \\
\text { alcohol }\end{array}$ & 100 & 100 & 100 & 100 \\
\hline $\begin{array}{l}\% \text { of total count } \\
\text { examine people }\end{array}$ & 39.4 & 54.5 & 6.1 & 100 \\
\hline
\end{tabular}

of kidney diseases in the exposed group, and could be due to professional exposure in the past.

3. There is no evidence of Cd contamination of drinking water.

4. The content of $\mathrm{Cu}$ and $\mathrm{Zn}$ in the serum of all tested individuals is within the referential boundaries.

5. The concentration of As in the urine samples of all tested individuals is within the referential values.

\section{REFERENCES}

1. Гопина Г.; “Токсични химични вещества в питейни води" - презентация, Национален Център по опазване на общественото здраве НЦООЗ-гр. София, Лаборатория” Хигиена на водите “, 2005 г.

2. Дряновски П.: Радиобиология, изд. “Земиздат”, София 1986 ,стр. 30

3. Луканов М.: Хигиена и професионални болести, Изд. "Медицина и Физкултура, 1983, стр.258-268

4. Смирнов В.И., Желязкова-Панайотова М.Д.,Гинзбург А.И., Григориев В.М., Яковлев Г.Ф.: Геология на рудните находища, изд. "Наука и изкуство”, 1986; стр.128-129 
5. Търновска Т., Иванов И., Петров П.: "Влияние на комунално-битовата среда върху някои хематологични показатели при работници от АЕЦ” Козлодуй”, стр.1-4

6. Цветков Д.: Хигиена том II Трудова медицина, Хигиена на труда, Професионални болести, изд." Св. Климент Охридски “, 2005, стр.208-218

7. Чаръкчиев Д.Д.: Лабораторна диагностика на професионалните болести и екопатологията, изд. “ Българска Издателска Къща"- ЕООД, 2006, стр. 187

8. Abadin H., Ashizawa A., Stevens Y.W, Llados F. "Toxicological profile for lead"; U.S.Department of health and human services, Public Health Service, Agency for Toxic Substances and Disease Registry, August 2007, pp.27-42

9. Basha MR., Brock B., Cox DP., Cardozo-Pelaez, etc.: Alzheimer's disease (AD)-like pathology in aged monkeys after infantile exposure to environmental metal lead $(\mathrm{Pb})$ : evidence for a developmental origin and environmental link for AD"; The Journal Of Neuroscience: The Official Journal Of The Society For Neuroscience [J Neurosci] 2008 Jan 2; Vol. 28 (1), pp. 3-9.

10. Bellinger DC.:'Late neurodevelopmental effects of early exposures to chemical contaminants: reducing uncertainty in epidemiological studies"; Basic \& Clinical Pharmacology \& Toxicology [Basic Clin Pharmacol Toxicol] 2008 Feb; Vol. 102 (2), pp. 237-44.

11. Joe M. Braun, Robert S. Kahn, Tanya Froehlich, Peggy Auinger, and Bruce P. Lanphear: "Exposures to Environmental Toxicants and Attention Deficit Hyperactivity Disorder in U.S. Children"; at http://www.who.int/publications, pp.1-6

12. Levengood JM., Heske EJ.:"Heavy metal exposure, reproductive activity, and demographic patterns in white-footed mice (Peromyscus leucopus) inhabiting a contaminated floodplain wetland"; The Science Of The Total Environment [Sci Total Environ] 2008
Jan 25; Vol. 389 (2-3), pp. 320-8. Date of Electronic Publication: 2007 Sep 27.

13. Vather M.:"Health effects of early exposure to arsenic"; Institute of Environmental Medicine, Karolinska Institutet, Stockholm, Sweden; Publication: Basic\&Clinical Pharmacology\&Toxicology [Basic Clin Pharmacol Toxicol] 2008 Feb.; vol.102(2), pp.204-11.

14. "Lead in air", section Health and Environmental, Environment Protection Agency - USA, at http://www.epa.gov/air/lead/health.html, last updated on Tuesday, april 8th,2008.

15. "Risk assesment for Toxic Air Pollutants": A Citizen's Guide, originally published as EPA 450/3-90-024 at http://www.epa.gov/air pollutants; March 1991, last updated on Wednesday, June 6th, 2007.

16. "Low dose ionizing radiation and cancer risk", Radiation protection 125; Proceeding of a scientific seminar held in Luxembourg on 9 November 2000" ;Luxembourg office for Official Publications of the European Communities, 2001: at http://europa.eu.int, ISBN 92-894-1693-9; European Communities, 2001; pp. 7-9

17. "Health effects of the Chernobyl Accident and Special Health Care Programmes", at http://who.int/mediacentre/factsheets/fs303/en/index.html publication April 2006, pp.1-5

18. "Radioactive Poloniumin in Tobacco, at http://www.acsa2000.net/HealthAlert/lungcancer.html pp 1-7

19. "Radioactive elements in Tobacco and Smoke" at http://www.healthservices. 100587 907gov.bc.ca/guildford/pdf/147/00014794.pdf, 22 yuli, 1986

20. "Health risk of heavy metals from long-range transboundary air pollution"; Joint WHO-convention Task Force on the Health Aspects of Air Pollution; at http://www.euro.who.int/document/E91044.pdf; ISBN 9789289071796 WHO-Europe 2007, pp.5-72 